\title{
Distribution of Wealth by Capital Markets: Myth or Reality?
}

\section{Nazlı Gamze AKSU SANSAR ${ }^{1 \oplus}$}

\begin{abstract}
Many books and countless articles have been written about capital markets. Most notably, these studies are technical (especially in the U.S.) and concern, for example, earning money from the stock markets. In 2008, following the onset of the global financial crisis, there were calls for changes in terms of the operation and regulation of global capital markets, mainly because of the short term "profit oriented" focus of investors, the need to compete with the new economy, and the loss of corporations' moral fiber in the management of funds. This situation has wounded the capital markets system and shaken investor confidence. Meanwhile after the crisis, as the problems and weaknesses of the system were lamented by many critics, a very important but somehow overlooked issue reemerged: do the stock markets really help in term of the creation and dispersion of wealth, as they initially promised to do?
\end{abstract}

One of the most important functions of stock markets is undoubtedly to ensure a balanced income and wealth distribution. This functions of the stock markets promise to serve economic, political, and social development objectives. In this context, stock markets were initially developed with the intention of "peoples' capitalism," in which the widespread dispersal of stockholdings meant dispersion of wealth to the masses.

In this paper various sources, covering governmental and academic research and statistics, are explored; and the history of the creation and development of wealth, corporate ownership, and control in Europe and the U.S. is delineated. As a result, in light of the information gathered, the paper concludes that stock markets have a notable role in the creation and dispersion of wealth. However, stockholdings in capital markets mainly accrue to wealthy minority groups in the form of funds and, again despite the public offerings, the management and control of companies resides with the same privileged groups. To prove this point a developed (the U.S.) and a developing (Turkey) capital market were investigated. Investor
${ }^{1}$ Assist. Prof. Dr., Beykent University, Faculty of Economics and Administrative Sciences, International Trade (English), Istanbul, Turkey

\section{Corresponding author/Sorumlu yazar:} Nazlı Gamze AKSU SANSAR, Beykent University, Faculty of Economics and Administrative Sciences, International Trade (English), Istanbul, Turkey

Phone/Telefon: +90-212-444 1997

E-mail/E-posta: nazligamzesansar@gmail.com

Date of receipt/Gelis tarihi: 12.09 .2017 Date of acceptance/Kabul tarihi: 28.09.2017

Citation/Atıf: Aksu-Sansar, N. G. (2017). Distribution of wealth by capital markets: myth or reality? Istanbul Journal of Economics, 67, 91-108. https://doi.org/10.26650/ISTJECON372371 
profiles, trends, and ownership structures were studied to determine if and how these two casestudy markets differ. As a result, it was concluded that in both markets the proportion of stockholders belonging to low-income groups is very small.

Keywords: Capital markets, stock markets, people's capitalism, distribution of wealth

\section{ÖZ}

Sermaye Piyasaları ile Servetin Yaygınlaştırılması: Efsane mi, Gerçek mi?

Yirminci yüzyılın sonlarına kadar, sermaye piyasaları hakkında birçok kitap ve sayısız makale yazıımıştır. Bu çalışmalar teknik düzeyde (özellikle ABD'de) ve daha çok sermaye piyasalarında kolay para kazanmak hakkında olmuştur. Ancak 2008 yılında sermaye piyasaları yaşanan küresel finansal krizle birlikte, rekabet etme intiyacı ve kaybın önlenmesi gibi nedenlerle sadece kâr odaklı olan yeni ekonomik düzeninin değişmesi gerektiğine tanık oldu. Bu durum sermaye piyasası sisteminin yaralanmasına ve yatırımcı güveninin sıkıca sarsılmasına yol açmıştır. Krizden sonra, sistemin hataları bir çok uzman tarafından tartışılmaya başlandığında, çok önemli ama bir şekilde şimdiye kadar göz ardı edilen diğer bir meseleyi de yeniden gündeme getirmiştir: Sermaye piyasaları servetin oluşumu ve yaygınlaştırılmasında gerçekten önemli bir yere sahip midir?

Sermaye piyasalarının en önemli işlevlerinden biri şüphesiz dengeli bir gelir ve servet dağıımıdır. Bu işlev, toplumun hem ekonomik hem de politik olarak gelişimine hizmet etmeyi ve toplumsal dengelerin kurulmasını kolaylaştırmayı taahhüt eder. Bu bağlamda, sermaye piyasaları başlangıçta "halk kapitalizmi" sloganı kullanarak geliştirilmiş, burada, servetlerin yaygın dağılımı zenginliğin büyük kitlelere dağılması anlamına gelmiştir.

Bu yazıda, çeşitli kaynaklar; konuyla ilgili resmi araştırmalar, akademik çalışmalar ve ilgili istatistikler araştırılarak, Avrupa ve ABD'de servetin oluşumu ve yaygınlaşması, şirket sahipliği ve kontrolü hakkındaki tarihsel ve güncel bilgiler ele alınmıştır. Sonuç olarak, kaynaklardan elde edilen bilgiler ışığında, makale, sermaye piyasalarının aslında servetin oluşumu ve yaygınlaştırılmasında belirgin bir rol oynadığını, fakat buna karşılık sermaye piyasalarındaki hisse senedi ve fon sahipliğinin çoğunlukla varlıklı zengin azınlık grupların elinde fonlar şeklinde toplandığı ve halka arzlara rağmen şirketlerin yönetim ve kontrolünün ise yine aynı grupların elinde olduğu sonucuna varmıştır. Bu sonucu pekiştirmek için; gelişmiş bir sermaye piyasası (ABD) ve gelişmekte olan bir sermaye piyasası (Türkiye) verileri kullanılmış, her iki farklı piyasanın yatırımcı profilleri, trendleri ve mülkiyet yapıları incelenmiştir. Sonuç olarak, her iki piyasada da düşük gelir grubunda olan yatırımcı sayısının ve pay sahipliği oranının çok önemsiz olduğu sonucuna varılmıştır.

Anahtar kelimeler: Sermaye piyasaları, borsalar, halk kapitalizmi, servetin yaygınlaştırılması

\section{EXTENDED ABSTRACT}

Since the 1980s, globalization and privatization have become inseparable concepts and have developed together in the world. The spread of globalization and privatization has been judged by some authors as a reflection of U.S. imperialism, but this has been countered by others who suggest that such an assertion treats and evaluates these subjects too ideologically. The reason for this is that the "liberal economic drake" under the leadership of the U.S. in the 1980s, has lived the most strenuous days. Especially after the 1990s, when the U.S.SR was effectively out of business, the world became unipolar and the liberal economic system became, at 
least ostensibly, incontrovertible. The years that followed, with the 2001 crisis in Russia, the Far East, and Brazil, and the world financial crisis which started in the U.S. in 2008, showed us that all may not be well with the liberal economy; thus the voice of anti-globalization began to rise.

Today, instead of these ideological slogans, it is necessary to investigate the evidence underlying these discussions. It is a fact that the global economy at the time of the 2008 crisis deeply embraced global capital markets as the engine of growth and equilibrium. However, this study is not focused directly on this crisis, but rather on investigating the distribution of wealth by the capital market system. The framework of the study emphasizes the interactions between securities exchanges, capital markets, investors, and the jointly owned stock companies and how these entities are linked with the development and distribution of wealth in general. In other words, capital markets are studied where wealth is formed in one direction and distributed in another.

First, it is important to determine how the Western capitalist countries, especially the U.S., have changed in the direction of globalization since the 1970s. Then, at today's point, it is necessary to evaluate the economic implications of this change, which firstly arise in modern joint-stock companies. In particular, it is pertinent to address the monopolistic managerial dominance or, some say "dictatorship," which is manifested in the gigantic multinational joint-stock corporations. Hitherto, these topics have been discussed and examined in various forms. Some authors have paid attention to the problems and deleterious consequences of these developments in the U.S. and other economies. Some even argue that these developments are essentially ignored by U.S. managers. But the crucial points of this argument are the encroachment, corruption, and swallowing of the real economy by the financial sector and how this exploitation affects the development and distribution of wealth among different income groups. For this reason, it is imperative that capital markets, which became the engine of the neoliberal economic system, are re-audited.

It is a well-known fact that capital markets are an alternative to investment banks vis-a-vis fund-raising for companies. Indeed, capital markets have emerged as the most important means of meeting the self-financing needs of these companies. In 
this article, the issue of distribution of wealth to the masses by capital markets has a special importance. It was envisaged that capital markets could and would function as an instrument to allocate wealth and that is why in the U.S. these markets were initially propagated in the name of "people's capitalism" with concomitant promises to spread the wealth to low-income groups. However, from our data it is clearly apparent that the point reached today is a complete disappointment in this regard.

In the initial parts of the article the development of capital markets, the main trends in the formation and dissemination of wealth in Western economies, the consequences of the contemporary evolution of Western companies, and the change in prevailing understandings of wealth are investigated. In the concluding part, the place and role of capital markets in the formation and dissemination of wealth, is examined.

Within this framework, U.S. and Turkish capital markets including the investor profiles of these markets are studied in terms of different income groups. The results are interpreted to determine if capital markets are, empirically, an effective tool for dissemination of wealth as promised by their proponents and adherents. As a conclusion, in light of the data gathered, we suggest that capital markets have reached the end of escalation of shareholder ownership in general. Nevertheless, the principal concern that should not be overlooked here is that the increased shareholding ratio does not necessarily translate to the economic equality promised under the people's capitalism mantra. The important problem that needs to be addressed here based on the data is that the amassing of stocks in the high income class hinders a balanced distribution of wealth.

Consequently, we can conclude that a broad middle class in the capital markets would be a more desirable situation both economically and socio-politically. Economic democracy is as central as political democracy in the social order. The realization of economic democracy depends, first of all, on fair distribution of economic wealth. Balanced distribution of wealth in society will contribute to the settlement of participatory democracy and the attainment of democracy by individuals, as economic democracy is preconditioned and individuals can take part in decision-making processes. 


\section{Introduction}

To understand the development of wealth, corporate ownership, and control trends worldwide, and to evaluate the distribution of wealth from this point of view, first it is imperative to determine how economic structures in Western countries, especially in the U.S., have moved toward globalization. Then it is necessary to evaluate the economic consequences of the change that first emerged in multi-partner modern companies.

Societies depend on the development of economic and political democracies. However, because of the intense pressure of globalization and competition, particularly in the U.S. (highlighted by the 2008 world economic crisis), societies are moving away from economic democracies and heading toward executive "dictatorships." In an era of increasing capital mobility and globalization, this trend has become more prevalent in the recent past.

Until now, these issues have been discussed and examined in various ways. Some authors, focusing on the negatives, have reflected on the U.S. and world economies. Some argue that the issue of "economic democracy" is ignored by U.S. managers. Nevertheless, the 2008 crisis justifies these criticisms, and the crisis spread around the world, ultimately calling into question the Western capitalist system. The crucial question is whether the real economy will be swallowed up by the financial sector. For this reason, it is imperative that financial firms, capital markets, and stock exchanges be audited.

In this paper, the role and importance of capital markets in the formation and dissemination of wealth are addressed. The academic literature, official research results and relevant indicators have been studied to explore historically how wealth has been created and dispersed through capital markets in the West (largely in the U.S. and Europe). Notably, this paper will try to determine if capital markets actually have a role in wealth distribution among different groups. 


\section{The Evolution of Capital Markets}

It is a well-known fact that capital markets are actively replacing investment banks in fund-raising for companies. In other words, capital markets have emerged as the most important means of meeting companies' self-financing requirements. Stock markets, in general, disseminate wealth broadly (Schmukler, 2014, pp. 4-6). In the United States, the stock market was initially seen as a channel to spread wealth to the masses. This was called the "people's capitalism."

Today, however, this description would be inaccurate. Since the early 2000s, the role of the U.S. capital markets has been widely debated. In May, 2000, an assistant of Alan Greenspan (the chairman of the Federal Reserve Bank) published an article in the Wall Street Journal stating that the stock market has a potent impact on FRB policies. Greenspan then said to his deputy, "I can really stop talking about the markets, but if I stop, I cannot explain to people how the process works ... It is impossible to understand the end of the economy without using stock prices as a reference." (Smith, 2004, p. 3). Greenspan is not alone in this opinion. Toward the end of the twentieth century, all businessmen and policy leaders in the world have had difficulty understanding the economic environment without paying close attention to capital markets, which can be variable, unpredictable, and often volatile.

Capital markets, which only a generation ago were often ignored and underestimated, now, suddenly, have become powerful institutions with a decisive role in national economies (Smith, 2004, p. 3). For millions of investors, stock markets now carry the hope of financial security and a comfortable retirement. In emerging markets, stocks provide a sustainable return on investment and avoid dangerous debt relief scenarios that can lead to economic friction (Smith, 2004, p. 4). At the same time, though stock investments can deplete retirement savings in a bear market.

In the late twentieth century, numerous books and articles were written about capital markets. Many focus on capital markets' impact on countries and societies. 
However, they largely do not focus on capital markets' role in the formation and distribution of wealth. This study will shed light on this topic.

\section{Main Trends in the Formation and Dissemination of Wealth in Western Economies}

When worldwide development of wealth and corporate ownership are examined, one encounters inside and outside systems. An outside system disperses ownership and wealth broadly, while an inside systems concentrates ownership or control. In outside systems, seen principally in the U.S. and the U.K., the conflict of interest is mainly between strong managers and widely-dispersed, weak shareholders. In inside systems, largely in Continental Europe and Japan, the conflict is between controlling shareholders and weak, minority shareholders. However, these variances are also influenced by disparities in countries' regulatory and institutional settings (Maher, \& Andersson, 1999, p. 4).

Historically, industrialization was first seen in Europe, where many class struggles took place, some involving capitalism. The United States, in contrast, created a middle class, beginning in the 1790 s, that participated in joint ventures and other capital market investments (Perlo, 1958, p. 333). Although the 1929 stock market crash shocked the U.S. economy, it recovered rapidly during the Second World War, after which the U.S. emerged as the world's greatest economic and political power. At that time, the U.S. also introduced a liberal, free market economic model to the world. However, the economic crisis of 2008 threw this entire system into question.

In Continental Europe, particularly in Germany, class struggles appeared after the Second World War, and Germany's economic development during and after the 1950s was intertwined with social solidarity. Workers and employers agreed upon a system that underlined a "politics of serving down." The Christian Democratic government, which had an important political impact, remained in power for many years, disseminating wealth to the working class and supporting unions. Supervisory boards were created in major German companies, where 
management and employee representation was mandatory. Now, in some heavily industrial areas (mainly, the steel and coal industries), workers' unions constitute half of the supervisory board. In other large companies, the General Assembly is equally divided into two, and shareholders choose a Chairman who settles tied votes. Medium- and small-scale companies, on the other hand, establish a Labor Council in place of labor representation in a General Assembly. German law has made it clear which decisions can be made only with the permission of this Council.

Opponents of the German system argue that cross-holding shareholders are often irresponsible and, in some cases, inadequate in managing a company, because they are isolated from the competitive pressures of capital markets. A series of crises in the 1990s at large German companies, including the collapse of the Schneider Group and Metallgesellschaft Company, seem to support this notion. Gunter Ogger, in his book entitled "Nitwits in Pinstripes," states that Germany's economic problems are "management mistakes caused by nontransparent distorted relations and established large block shareholding system." Therefore, pressure for system-wide reform was heavily influenced by foreign investors, because foreign investors in the German capital market found the German Cooperation System complex yet sufficiently transparent (Smith, 2003, p. 26). German Chancellor Schröder has restructured the state pension system to encourage retirement, mostly using equity investments and retirement savings. Beginning in 2002, beneficiaries were allowed to invest in insurance products or mutual fund-type investment products, totaling up to $1 \%$ of German depositors' tax-free income (savings accounts), increasing to $4 \%$ in 2008.

American capital markets, in contrast, are driven by pension funds. In 2001, private U.S. pension assets averaged $\$ 23,780$ per person, versus $\$ 3,800$ in Germany and \$1,600 in France. Many observers have seen this as a failure and a critical weakness of the European capitalist model. However, especially after the 2008 financial crisis, it is seen that money pools in the U.S., especially pension and home mortgage funds were actually overinflated and proved the critics of the European system wrong. 
It is difficult to find U.S. wealth-related data before the 1960s. Only tax records are available. U.S. income tax statistics, though, have been saved since 1913, the same year the federal taxation system went into effect. However, these statistics provide information only about taxpayers. Since then, various studies have been done about the creation and distribution of wealth in the U.S. (i.e., Wolff, (1989)). According to Wolff, between 1900 and 1983, national income per capita increased by $1.46 \%$, and real income rose $0.81 \%$. Income growth between 1900 and 1983 was not stable; it rose quickly in the 19001929 and 1949-1969 periods but grew more slowly in other periods (Wolf, 1989, pp. 5-7).

During the $19^{\text {th }}$ century, real wealth per capita increased more than the real income per capita and income per capita. In the twentieth century, households also experienced significant changes in wealth. In particular, while assets and property values grew more than total assets, the rate of share ownership within total assets has declined. The cost of living increased from $17 \%$ in the 1900 s to $20 \%$ in 1983. Among financial assets, the biggest increase occurred in investment trusts, from $8 \%$ in 1900 to $22 \%$ in 1983 . Share ownership as a percentage of total assets was $13 \%$ in $1900,27 \%$ in $1927,10 \%$ in $1949,22 \%$ in 1965 , and $11 \%$ in 1983 . Finally, the proportion of retirement reserves and social security wealth reached $12 \%$ and $48 \%$, respectively, in 1983 , from zero in 1900 (Wolf, 1989, p. 10).

\section{Consequences of Modern Western Company Evolution}

The evolution of the modern U.S. company fundamentally transformed global wealth. In 1932, the work of Berle and Means, "Modern Corporations and Private Property," was revolutionary. Their work on publicly-held companies became the first detailed study of so-called "people's capitalism." Berle and Means noted a strong relationship between the evolution of company systems and the changing scope of ownership in their research. According to the authors, the evolution of a company's structure is the main cause of a changing scope of ownership. 
After the American civil war, the American economic structure changed into the concept of proprietorship of the company. The feudal structure in the West and the emerging industrial revolution allowed American businesses to achieve high profits in the industrial sector. Since 1990, growth in the volume and scale of business has been the cornerstone of today's modern "company system" (Mizruchi, 2004, p. 2). Today's businesses are mixed; they are either a productive ownership or a "Corporate System" and the ownership concept considers all means necessary for production, transportation, distribution, and sales. As a result, modern ownership extends from a vendor organization, employeeemployer relationship, and managerial hierarchy to technical specialists. This creates a new economic concept (Adolf, \& Gardiner, 1968, p. 54).

A shift in attitude in modern corporate ownership arose from a changing source of financial capital. The wealth of modern companies is more productive than personal consumption. But more importantly, wealth is no longer the end result of personal effort or choice but a consequence of an entire organization or a result of a changing system. An established modern company is financed largely by undistributed profits and amortization. This accounted for $60 \%$ of total funding in the 1930 s, $26.2 \%$ of undistributed profits in 1980 , and $42.24 \%$ of the wear allowances (Adolf, \& Gardiner, 1967, 18). It is important for us to see how important executive classes are for modern companies and the power of managers in financial decision-making. Non-distributed profits, which are accumulated in companies, constitute a new capital resource, which is directed toward investments and production. As a result, the need for banks and personal assets has gradually decreased. A typical modern and well-established joint-stock company does not need much outsourcing for investment capital. Even if its own undistributed profits and provisions are not sufficient for this new investment capital, if the company succeeds, its success precedes it when accessing capital markets (Mizruchi, 2004, p. 25).

Modern joint-stock companies, as the legal owners of collective capital, thus have the power to make complete decisions. Therefore, these types of companies continue to grow within the new system. On the other hand, shareholders have 
lost their former position and now accumulate profits by owning transfer-free assets. As a result, modern company management strangely has become an uncontrollable entity with permanent accumulation privileges. However, shareholders only passively benefit from the new system. Roe (1994) notes that in comparison with other countries, the density of small ownership in the U.S. may result from policies initiated by controlling managers of large holdings (e.g., devices that prevent inheritance). In the U.S., this suggests that these managers are stronger than shareholders and that the strengthening of management is a serious problem (Roe, 1994, p. 263).

It is also evident that legislation has been removed to protect and handle this remarkable phenomenon. This fact may arise perhaps from an ongoing trend. In particular, it should be noted that legal rules require that the use of reserved property (wealth) in the hands of the executives more or less meets the evolving expectations of American society. However, it should not be forgotten that the 2008 financial sector crisis encompassed both the U.S. and the whole world. In the face of this situation, the United States and all the countries in the world tended to re-regulate the system.

\section{Changing the Understanding of Wealth}

With industrial sector growth, U.S. introduction of the multilateral joint-stock company system transferred productive property (securities investments) through stocks and bonds to the economy. Thus, the main change in the economic structure is in "people's capitalism" or the "Corporate System." In large, publicly traded companies, stocks and other types of securities have become authoritative. This directly influenced production. Forms of wealth are divided into production and consumption. Production wealth consists of savings, investments, and investment property (real estate and securities). This study looks at the investment property of securities.

Securities, mainly stocks and bonds, are a new type of productive asset that changes the nature of property. As a result, a new ruling class inevitably emerges, 
especially in an industrial society. Lawmakers who choose to form a "managerial class" separate the company and its shareholders from management. The managerial class has productive ownership, while the others have passive ownership. Passive ownership can be divided into three groups: stocks owned either by individuals or families, intermediary institutions (retirement funds, banks, and mutual funds), and other financial institutions (such as insurance companies) (Yüksel, \& Rodoplu, 1980, p. 6).

In the United States, the number of shareholders is increasing, while their controlling power in the management of large corporations is declining. Nevertheless, shareholders still have the power to influence management in certain situations, such as bad governance or dishonest behavior. Formation of a general meeting of shareholders, in which all shareholders participate, limits management's power.

Early capital market development in the U.S., accelerated the organization of investment-oriented investment securities, publicly-held multinational corporations, and "people's capitalism." These events altered the definition of wealth. Ownership of stocks and negotiable instruments became more important, and property laws were rearranged with these new conditions.

Changes in the U.S. property system have increased personal fortunes. Securities investment wealth, a large part of the wealth that makes up personal wealth, is concentrated in stocks. Stock appreciation has been crucial in the development of the American economy.

In the U.S. today, stock ownership is either productive (managerial) or passive. The growing size and dominance of American companies have dissembled the rights and privileges of the old property system. In this new, modern corporate structure, the individual investor is completely separated from company management. Passive ownership, nevertheless, has satisfied many Americans, who still invest in stocks. In 1929 there were 4-5 million Americans' shares. At the end of 1967, this figure reached 23 million, accounting for about a third of private 
individuals' wealth in the United States. In 2004, it accounted for nearly 50\% of this segment's total wealth (Xiao Di, 2010, p. 19).

2004 was the apex of passive stock ownership. Now, the highest percentage of stock is owed by financial institutions, particularly pension funds. Mutual funds are the next largest holders of stocks, followed by life insurance companies, who invest about 3\% of their assets in stock (Wolff, 2007, p. 37).

According to a recent Survey of Consumer Finance conducted by the Federal Reserve, the lowest level of stock ownership in the U.S. occurred in 2013 (the lowest level since 1995). However, wealthy U.S. individuals are buying more stock. The Survey states that in 2012, stock ownership in the U.S. was only 48.8 percent. For middle-class households (with incomes from $\$ 30,000$ to $\$ 74,999$ ), the percentage, prior to the 2008 economic crisis, was above $70 \%$. Stock ownership of lower-income households (with incomes below $\$ 30,000$ ) remained marginal, while the percentage for high-income households (with incomes above $\$ 75,000$ ) remained stable, near 90\% (since 2007). The financial crisis in 2008 had little effect on high-income households' stock holdings in the U.S. Their rate of their stock ownership is almost twice that of the middle class and much more than the percentage for low-income households.

Table 1. Percentage of Americans who Indirectly or Directly Held Stocks

\begin{tabular}{|l|c|}
\hline Year & Stock Owners/Population \\
\hline 1989 & $32 \%$ \\
\hline 1992 & $37 \%$ \\
\hline 1995 & $41 \%$ \\
\hline 1998 & $49 \%$ \\
\hline 2001 & $53 \%$ \\
\hline 2004 & $50 \%$ \\
\hline 2007 & $53 \%$ \\
\hline 2010 & $50 \%$ \\
\hline 2013 & $49 \%$ \\
\hline
\end{tabular}

Source: Federal Reserve 
Table 2. Percentage of U.S. Stock Owners, by Age and Income

\begin{tabular}{|l|c|c|c|}
\hline & $\mathbf{2 0 0 7}$ & $\mathbf{2 0 1 0}$ & $\mathbf{2 0 1 5}$ \\
\hline$\$ 75,000$ and over & $90 \%$ & $92 \%$ & $88 \%$ \\
\hline$\$ 30,000-\$ 74,999$ & $72 \%$ & $61 \%$ & $56 \%$ \\
\hline Less than $\$ 30,000$ & $28 \%$ & $24 \%$ & $21 \%$ \\
\hline
\end{tabular}

Source: Gallup's Annual Economy and Finance Survey

Since the 1980s, stock ownership demonstrated a scatter pattern. As a result, stock ownership has been unevenly distributed to different income and occupational groups. This result questions the success of "people's capitalism." On the one hand, research figures indicate that share ownership is increasing (Despite experiencing ups and downs, share ownership rate in the U.S. is much higher than in many other countries). We can safely say that "people's capitalism" has reached its goal of greater shareholder ownership. This, however, is different from the economic democracy promised by "people's capitalism." The vital question is: who are the shareholders? A true economic democracy requires a strong middle class, whose social welfare can be achieved. The research, though, shows the opposite. Stock accumulation among a limited group of wealthy individuals prevents a balanced distribution of wealth (Bricker, et al., 2014).

Developing markets show virtually the same situation. In the Turkish stock market (the Borsa Istanbul), stock ownership is well distributed to a large investor base. A June, 2017 report by the Central Registry Agency and the Association of Turkish Investor Relations outlines Turkish stock ownership. As of June 2017, foreign investors' stock holdings totaled $65 \%$ of the entire Borsa, but only one percent of the total number of investors. Nearly 1.1 million investors in domestic real estate owned only $34.9 \%$ of total portfolio value. The share of the top ten domestic individual investors was about three percent. Their portfolios totaled 424.2 million $T L$, and the share of the hundred largest domestic individual investors was almost 6 percent. The share of close to one million domestic individual investors was only about three percent, and the average portfolio size was around four thousand TL. On the other hand, the total value of shares held 
by foreigners was 202 billion TL, with foreign institutional investors holding $36 \%$. In the first half of 2017, the three countries with the highest portfolio value in the Borsa Istanbul were the U.S., the U.K., and Luxembourg. 1,258 investors based in the U.S. held $34 \%$ of total foreign investments, while portfolios from the U.S., U.K., and Luxembourg totaled 55\%. Although the Turkish investor base is wide, a very few foreign and domestic corporations own and control the stock market (Stock Trades Report: June, 2017, pp. 14-18).

\section{Conclusion}

Humanity has long struggled to achieve political democracy. But for economic democracy to develop, a large part of the populace should share in production and governance. In the $20^{\text {th }}$ century, intensive efforts were made to integrate political and economic democracy. The realization of economic democracy depends, first of all, on a balanced distribution of economic prosperity. Balanced distribution of wealth in society contributes to participatory democracy and individual participation in the decision-making process. There is no doubt that the middle class is the pole of a strengthened society.

The distribution of wealth through capital markets and stock exchanges provides an opportunity for economic democracy. Securities also increase wealth through direct investment of small savings amounts, which provides more efficient use of capital.

The emergence of the multilateral joint-stock company system in the U.S. resulted from the transition to productive property. Thus, with the birth of "people's capitalism" or a "Corporate System," stocks and bonds became the most authoritative financial instrument for large, publicly traded corporations. Consequently, early formation of the U.S. capital markets established the investment-oriented portfolio, which allowed publicly-owned multinationals to accelerate public capitalism in an important and effective way. Development of capital markets also altered our understanding of wealth, and property laws were altered according to these new conditions. 
In the U.S., after the 1900s, the slogan "people's capitalism" suggested that wealth would be disseminated broadly via the capital markets In part, this goal was achieved. Until the 1980s, stock ownership spread throughout the economy. After the 1980s, though, globalization took over the finance sector, with a large percentage of the stock market being held by a small number of corporations and wealthy individuals. Although many multilateral companies are publicly held, their executives are mainly professional managers, who do not have high stock ownership in the company. In the U.S., control of companies has shifted to institutional shareholders, particularly different types of funds and large banks.

Large partnerships in the United States created a new professional executive class, on top of shareholders. This type of organization makes it difficult to organize a general assembly that can reach thousands of shareholders (Jensen, \& Meckling, 1976, pp. 307-310). Business law gives executives a proxy to represent absent shareholders. These managers elect the board of directors, and this board, by choosing company managers, form a closed circuit. As a result, the system becomes increasingly corrupt. This form of managerial dominance leads to a form of executive dictatorship, which can create huge cases of fraud (as seen in Enron's bankruptcy). This calls for a more democratically structured corporate hierarchy.

Capital markets exist so that investors can invest their savings securely in securities and attain greater wealth. Thus, the ability to invest savings in securities is vital. U.S. capital markets, with the propagation of "people's capitalism," promulgated the idea that wealth could be distributed widely to the middle class. After the 1990s, though, stock ownership became concentrated in the hands of a small, rich minority. In addition, as stock ownership become more widespread, control of company management passed from shareholders to professional managers. This is very striking, because those who promised to spread the wealth to the "people" in the name of "people's capitalism" eventually formed a plutocracy of the rich. Both the capital markets and the stock markets influenced these developments.

Learning from U.S. history, placing savings in the hands of a broad middle class is a desirable, both economically and socio-politically. Economic democracy 
in a society is as important as political democracy. Therefore it is imperative to allow middle-class participation, as much as possible, in financial markets. Otherwise, as seen in the U.S., managers will control companies, which could lead to greater monopolization. Therefore, political, economic, and social equilibrium in a democracy is essential.

\section{References}

Adolf, A. B., \& Gardiner C. M. (1968). The modern corporation and private property. New York: Harcourt, Brace and World.

Bricker, J., Dettling, L., Henriques, A., Hsu, J., Moore K., Sabelhaus, ... J. Windle, R. (2014.) Changes in U.S. family finances from 2010 to 2013: Evidence from the survey of consumer finances. Federal Reserve Bulletin, 100(4).

Jensen, M. C., \& Meckling, W. H. (1976). Theory of the firm: Managerial behaviour, agency costs and ownership structure. Journal of Financial Economics, 3(4), 305-360.

Maher, M., \& Andersson, T. (1999). Corporate governance: Effects on firm performance and economic growth. Organisation for Economic Co-Operation and Development. Retrieved from https:// www.oecd.org/sti/ind/2090569.pdf

Mizruchi, M. S. (2004). Berle and means revisited: The governance and power of large U.S. Michigan: Corporations, University of Michigan.

Merkezi Kayıt Kuruluşu. (2017, June). TÜYiD. Borsa Trendleri Raporu XXI Haziran 2017. (s. 14-18). Erişim adresi: https://www.mkk.com.tr/tr/content/Bilgi-Merkezi/Borsa-Trendleri-Raporu,

Perlo, V. (1958). People's capitalism and stock-ownership. The American Economic Review, 48(3), 333-347.

Roe, M. J. (1994). Strong managers, weak owners: The political roots of American corporate finance. Princeton, NJ: Princeton University Press.

Schmukler, S. L. (2014, June). Benefits and risks of financial globalization: Challenges for developing countries. World Bank Policy Research Report "Globalization, Growth, and Poverty. Retrieved from http://siteresources.worldbank.org/DEC/Resources/BenefitsandRisksofFinancial GlobalizationSchmukler.pdf

Smith, B. M. (2003). The equity culture: The story of the global stock market. New York: Farrar, Straus and Giroux.

Smith, B. M. (2004). A history of global stock market, from ancient Rome to silicon valley. Chicago: University of Chicago Press.

Yüksel, A. S. ve Rodoplu, G. (1980). Sermaye piyasası. İstanbul: Filiz Kitabevi.

Wolf, E. N. (1989). Trends in aggregate household wealth in the U.S., 1900-83. Review of Income and Wealth, 34(3), 1-29. 
Wolff, E. N. (2007). Recent trends in household wealth in the United States: Rising debt and the MiddleClass squeeze. New York: The Levy Economics Institute of Bard College and New York University. Zhu Xiao Di (2010, May) "Growing Wealth Inequality, and Housing in the United States", Joint Center for Housing Studies Harvard University. Retrieved from http://www.jchs.harvard.edu/research/ publications/growing-wealth-inequality-and-housing-united-states 